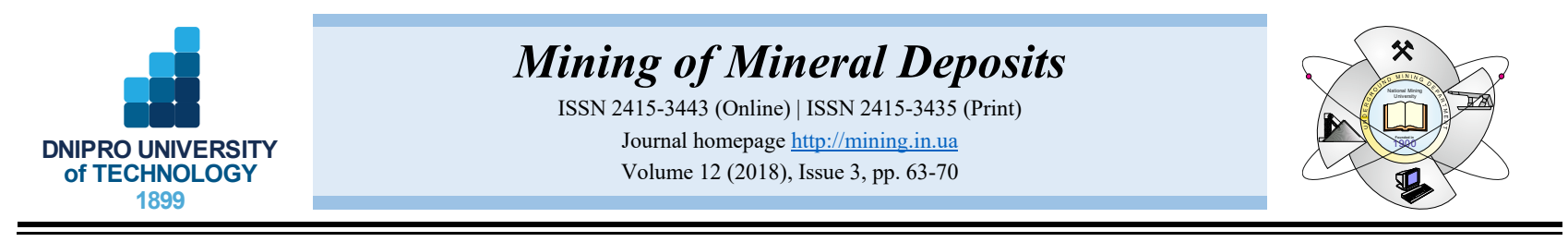

UDC 504.55.054:622(470.6)

https://doi.org/10.15407/mining12.03.063

\title{
IMPROVEMENT OF HOLE DRILLING TECHNOLOGY FOR ORE DRAWING INTENSIFICATION
}

\author{
V. Golik ${ }^{1}$, V. Morkun ${ }^{2 *}$, N. Morkun ${ }^{2}$, I. Gaponenko ${ }^{2}$ \\ ${ }^{I}$ North Caucasian Mining and Metallurgical Institute (State Technological University), Vladikavkaz, Russian Federation \\ ${ }^{2}$ Kryvyi Rih National University, Kryvyi Rih, Ukraine \\ *Corresponding author: e-mailmorkunv@gmail.com, tel.+380936770659
}

\begin{abstract}
Purpose. The improvement of hole drilling for increasing the mineral recovery ratio by ore drawing improvement through blasting.

Methods. The drilling parameters were examined for rock dumps. The means of experimental drilling are drilling rig SKB-4; drill rods with a diameter of $42 \mathrm{~mm}$ and a length of $1.2 \mathrm{~m}$; polyethylene pipes PND $63 \times 8$ and PND $70 \times 8$ with a length of $1.2 \mathrm{~m}$; steel couplings for polyethylene pipes connecting; cone bits and RKS cutters. The criterion of drilling efficiency was the mechanical drilling speed. The drilling speed at different depths was measured with an axial force of $800-2000 \mathrm{~kg}$ and rotational speeds of 120, 200 and $280 \mathrm{rpm}$. Experimental drilling was carried out using the charges of two modifications. 18 experimental boreholes with a length of $300 \mathrm{~m}$ were drilled.
\end{abstract}

Findings. The article confirms possibility and practicability of simultaneous hole drilling and pipe casing without transmitting torque loads on the pipes and offers a design of a drill string with hoses inside drill rods and their further pulling up, and piping with simultaneous drilling. The scheme of interaction of blastholes and pipe casing when hole boring in broken ores is made. The nature of the relationship between the speed of penetration of vertical and horizontal holes with the change in the axial force and their length for different modifications of the drilling tool is studied.

Originality. The new laws of change in the hole drilling penetration speed depending on the complex of technological parameters of drilling are obtained. The authors offer a model describing the possibility of hole drilling in the broken massif as well as an optimized design of the string necessary for that.

Practical implications. The obtained regularities determine mechanical and energy drilling indexes and which are necessary at the stage of designing when deciding upon practicability of extraction of in-situ left ores while enhancing mining technologies of ore drawing.

Keywords: improved ore drawing, packed ores, blasthole, drilling string, casing pipe

\section{INTRODUCTION}

In underground ore mining, there are ores, which are broken, yet, not hoisted onto the surface. Ore properties, work organization and other factors define the ability of some minerals separated from the massif to lose their mobility in ore drawing, which decreases ore caving indices. Their secondary processing is characterized by metal losses in the incomplete ore drawing.

The efficiency of mineral resources use in enhanced ore drawing is increased by optimizing sizes and procedures of arranging drawing workings by means of blast waves, water, etc.

The most widely used technologies include:

- blasting highly-explosive shells generating a blast wave affecting the lower part of hanging ores;
- ablation by water flows fed to the upper part of the ore overhang;

- firing the overhang from below with installations like grenade launchers, etc.

The mentioned steps are of low efficiency in mining packed, consolidated ores and the ones colmataged by natural leaching products. The ore drawing enhanced through blasting is more efficient. In the vicinity of blastholes, a net of macro-fractures is formed facilitating the movement of ore lumps and ores.

Ore drawing initiation by explosive charges in holes drilled in broken ore allows reducing ore losses and increasing operating costs at the same time. Therefore, hole boring should be technically and economically substantiated.

(C) 2018. V. Golik, V. Morkun, N. Morkun, I. Gaponenko. Published by the Dnipro University of Technology on behalf of Mining of Mineral Deposits. This is an Open Access article distributed under the terms of the Creative Commons Attribution License (http://creativecommons.org/licenses/by/4.0/), which permits unrestricted reuse, distribution, and reproduction in any medium, provided the original work is properly cited. 
While forming economic market relations, enterprises are looking for ways to increase their competitiveness and using the reserves never applied before including the tied-up ones.

Under certain conditions, lost ores brought into development compensate mining expenses and provide profits. Thus, it is quite urgent to develop technological solutions to increase the mineral recovery ratio by ore drawing improvement through blasting in broken ores (Bubnov et al., 1992; Bowman, 2016; Demchenko, Evtekhov, \& Georgiieva, 2017; Iofis, Fedorov, Yesina, \& Miletenko, 2017).

\subsection{Previous research studies}

Soviet scientists were the first to explore ore drawing. Investigations carried out by S.S. Minaiev and D.L. Tartakovskyi in the 1930s were continued by G.M. Malakhov, M.I. Agoshkov, V.V. Kulikov, N.G. Dubynin, V.R. Imenitov, S.L. Iofin, V.A. Shestakov and others, their researches creating a concept of the problem under study. Issues of hole boring in broken ores were investigated by V.N. Mosints, Yu.N. Smirnov and others.

They studied the problems of improving the mineral recovery ratio by applying technological impacts of on the packed broken ore in order to destroy structures of naturally blocked ore joints.

Holes in broken hard ores and rocks are bored when it is necessary to get a cavity maintained during operations. Methods of supporting hole walls by liming, silication, cementation, etc. are appropriate for relatively stable rocks. Pipe casing is a radical method of supporting hole walls (Benardos, Athanasiadis, \& Katsoulakos, 2014; Golik, Komaschenko, Morkun, \& Burdzieva, 2015; Luk’yanov, Komashchenko, \& Shmurygin, 2017).

For hole boring such drilling methods are applied as percussive-swinging, rotary, rotary-percussive and percussive-rotary. Advantages of the rotor method compared to others include:

- a simple, reliable and expensive design of drilling equipment because of the absence of dynamic components;

- lower energy consumption: per $1 \mathrm{~m}$ of hole boring in rocks of $6-12$ hardness by Protodyakonov scale $2.5-3.5 \mathrm{~kW} / \mathrm{h}$ (by pneumatic perforators) and $0.3-1.0 \mathrm{~kW} / \mathrm{h}$ (by hydroperforators) are consumed;

- lower hazards of contamination of dusting, noise, vibration and aerosols.

The most promising is simultaneous drilling and pipe casing without transmitting torque loads on the pipes consisting of a drill bit, an external non-rotating pipe and an internal pipe or a rod (Fig. 1).

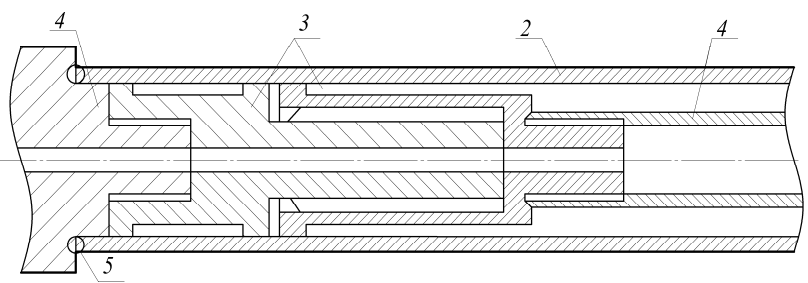

Figure 1. The scheme of a string for arranging pipes in hole drilling on the broken ore: 1 - a set of drills; $2-$ a casing pipe; $3-a$ splined separator; $4-$ an adapter; 5 - a welding seam
A drill bit is embedded into the rock and drags pipes into the hole without rotating them, thus, reducing time for hole making. Deletion of torque loads transmitted to the pipes is the basic way to improve this method.

Basic results of research works in this field include:

- creation of theoretical preconditions to develop designs of drilling strings and casing pipes;

- determination of loads on casing pipes resulted from resistance to shifting pipes considering friction of casing pipes in relation to rocks;

- development of methods to assess conditions of broken ores according to the mechanical penetration speed.

\subsection{Aims and tasks}

The research aims to improve hole boring and increase the mineral recovery ratio by enhancing ore drawing through blasting.

The tasks of the research involve determining regularities of:

- destruction of a structure of packed ore joints;

- interaction of a drilling sting and ore in hole boring.

The research tasks include:

- determining the mechanical penetration speed depending on the mode;

- specifying loads on casing pipes when exposed to rocks;

- determining the drilling depth and the capacity required for this in response to the axial load formed by the machine.

The research is aimed at developing designs of a drilling string for pipe casing with hoses inside drill rods and their further pulling up, and piping with simultaneous drilling.

\section{MATERIALS AND METHODS}

The research structure includes analysis of practices, laboratory and natural investigations, description of their results by means of mathematics and information technologies, and determination of economic and environmental efficiency of solutions.

The research is based on simulation of parameters of ore drawing and drilling in broken ores.

During the natural experiment in drilling boreholes ore samples considering their location in space. The results of investigating the samples are the basis to recalculate reserves and make decisions as for their extraction. Devices for investigating conditions of broken ores are placed into the drilled hole.

The research results are used to substantiate environmental and economic efficiency of possibility and expedience of secondary mining of technogenic reserves.

Drilling string options with and without pipe rotation are under study (Fig. 2) (Gur'yeva, 2009). In laboratory investigations, a $2.5 \mathrm{~m}^{3}$ mine trolley was used as a bunker. A drilling rig ZIF-650M was used to broach $32-90 \mathrm{~mm}$ polyethylene pipes. The rock overload was performed by hydraulic jacks of $2 \mathrm{t}$ lifting capacity each located on three traverses. The broaching velocity was $10-80 \mathrm{~cm} / \mathrm{min}$ depending on the pipe diameter. The rock density characterized by the fragmentation index was created with a vibrator. The process parameters were recorded by a system of sensors. 
(a)

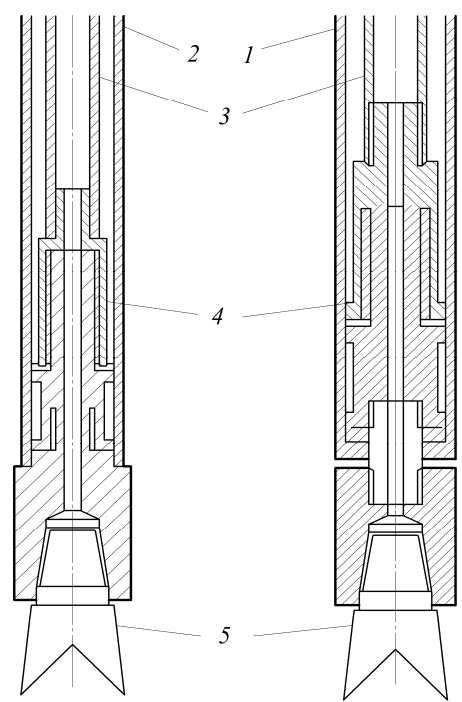

Figure 2. Drilling strings and pipe casing: (a) with rotation; (b) without rotation; 1 -a polyethylene pipe; $2-a$ metallic pipe; 3 - a drilling rod; 4 -a splined joint; $5-a$ bit

Drilling parameters were investigated at the rock dump (Fig. 3). (a)

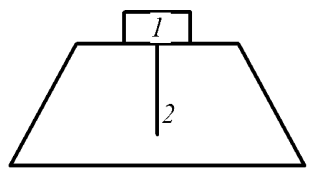

(b)

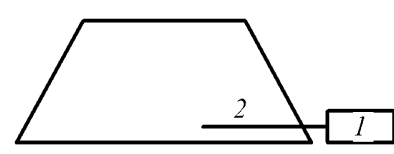

Figure 3. The scheme of drilling: (a) horizontal; (b) vertical holes; 1 - a drilling rig; 2 - a blasthole

Experimental drilling means include a drilling rig SKB-4, $42 \mathrm{~mm}$ drill rods $1.2 \mathrm{~m}$ long, polyethylene pipes PND $63 \times 8$ or PND $70 \times 81.2 \mathrm{~m}$ long; steel couplings to connect polyethylene pipes, roller bits and cutters RKS. In experimental drilling there were used strings of two types - without transmitting torque loads on the pipes (without rotation) and pipe casing by rotating them. Figure 4 shows a string for simulating the first option.

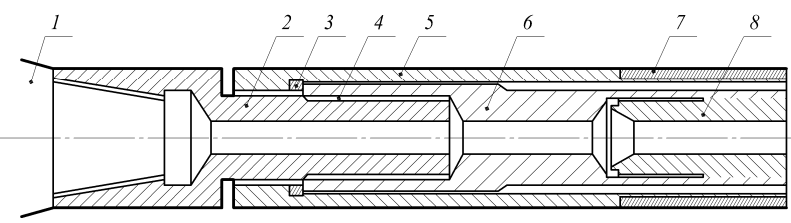

Figure 4. The design of the drilling string: 1-roller bits; 2 -a splined shaft-adapter; 3 -washer; 4 -splines; 5-coupling; 6-a splined cup; 7-a polyethylene pipe; 8 - a drilling rod

The coupling 5 was mounted to rotate freely as to the splined shaft-adapter 2 . The second option differed by the fact that the coupling 5 was fastened to the splined shaft-adapter with the left thread aimed to connect pipes. The mechanical penetration speed was the efficiency criterion of drilling. There were 18 drilled blastholes $300 \mathrm{~m}$ long with $266 \mathrm{~m}$ metallic casing pipes and $34 \mathrm{~m}$ polyethylene ones. The maximum depth of experimental holes was $22 \mathrm{~m}$ with metallic pipe casing and $9 \mathrm{~m}$ with polyethylene pipe casing. The penetration speed at different depths was measured under the axial load of $800-2000 \mathrm{~kg}$ and rotation speeds of 120, 200 and $280 \mathrm{rpm}$.

\section{RESULTS AND DISCUSSION}

The absolute maximum rotation speed was $320 \mathrm{~cm} / \mathrm{min}$, the minimum was $5 \mathrm{~cm} / \mathrm{min}$; the average was $110 \mathrm{~cm} / \mathrm{min}$ (Table 1, 2).

Table 1. The penetration speed under the axial load of $800 \mathrm{~kg}$

\begin{tabular}{cccc}
\hline Rotation & \multicolumn{3}{c}{ Penetration speed, cm/min } \\
\cline { 2 - 4 } speed, rpm & minimum & average & maximum \\
\hline 120 & 5 & 35 & 53 \\
200 & 16 & 57 & 102 \\
280 & 54 & 93 & 160 \\
\hline
\end{tabular}

Table 2. The penetration speed under the axial load of $2000 \mathrm{~kg}$

\begin{tabular}{cccc}
\hline Rotation & \multicolumn{3}{c}{ Penetration speed, cm $/$ min } \\
\cline { 2 - 4 } speed, rpm & minimum & average & maximum \\
\hline 120 & 66 & 86 & 126 \\
200 & 87 & 167 & 244 \\
280 & 148 & 222 & 320 \\
\hline
\end{tabular}

The penetration speed reduced with the depth increasing as the axial load was mostly used to shift the pipe (Table 3).

Table 3. Dynamics of the penetration speed with polyethylene pipe casing

\begin{tabular}{ccccccccccc}
\hline \multirow{2}{*}{ Axial load, kg } & \multicolumn{10}{c}{ Drilling depth, $\mathrm{m}$} \\
\cline { 2 - 10 } & 1 & 2 & 3 & 4 & 5 & 6 & 7 & 8 & 9 & 10 \\
\hline 800 & 166 & 158 & 135 & 119 & 105 & 87 & 56 & 38 & 16 & 5 \\
2000 & 320 & 286 & 195 & 144 & 115 & 92 & 81 & 71 & 62 & 55 \\
\hline
\end{tabular}

The slip speed of pipes was $5 \mathrm{~cm} / \mathrm{sec}$. The load of pipe tension was variable. The friction ratio, the number and size of cuts increased with depth. The results of experimental drilling allow stating that:

- drilling with roller bits is possible in rocks of any hardness;

- the maximum hole depth is $35 \mathrm{~m}$;

- drilling in rocks of up to 12 hardness is efficient with a cutting instrument and those of more than $12-$ with a roller bit or a diamond bit.

Drilling efficiency in broken ores made $15 \mathrm{~m}$ per shift of the ready-made hole with pipe casing.

The penetration speed under the axial load of $800-2000 \mathrm{~kg}$ and the rotation speed of 120,200 and $280 \mathrm{rpm}$ was maximum $(320 \mathrm{~cm} / \mathrm{min})$, minimum $(5 \mathrm{~cm} / \mathrm{min})$ and average $(110 \mathrm{~cm} / \mathrm{min})($ Table 4,5$)$.

Table 4. The penetration speed under the axial load of $800 \mathrm{~kg}$

\begin{tabular}{cccc}
\hline Rotation & \multicolumn{3}{c}{ Penetration speed, cm/min } \\
\cline { 2 - 4 } speed, rpm & minimum & average & maximum \\
\hline 120 & 8 & 42 & 76 \\
200 & 28 & 77 & 126 \\
280 & 54 & 123 & 192 \\
\hline
\end{tabular}

The penetration speed with polyethylene pipe casing decreases in the same way as under the axial load of $800 \mathrm{~kg}$ (Table 6). 
Table 5. The penetration speed under the axial load of $2000 \mathrm{~kg}$

\begin{tabular}{cccc}
\hline Rotation & \multicolumn{3}{c}{ Penetration speed, cm $/$ min } \\
\cline { 2 - 4 } speed, rpm & minimum & average & maximum \\
\hline 120 & 86 & 172 & 258 \\
200 & 137 & 216 & 296 \\
280 & 168 & 260 & 351 \\
\hline
\end{tabular}

Table 6. Dynamics of the penetration speed with polyethylene pipe casing

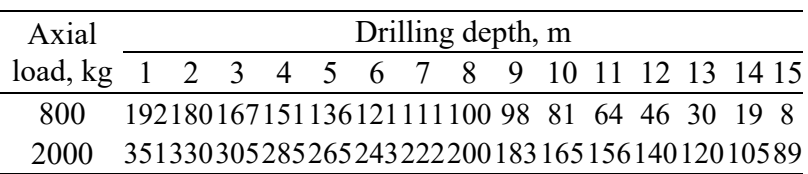

Kinematics and dynamics of the drilling string operation, the penetration speed and capacity as well and the drilling depth depend on resistance to the pipes drag considering friction (Olovyannyy, 2016; Golik, Komashchenko, Morkun, \& Burdzieva, 2017). In rotary drilling under the axial load and torque, a breaking instrument (an indenter) is in constant contact with rocks. The indenter should be connected to the pipes mounted simultaneously with drilling without delivering any torque loads on them (Fig. 5).

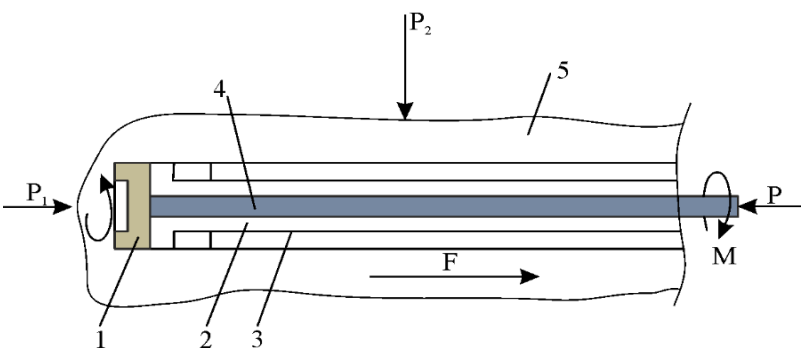

Figure 5. The scheme of interaction of blastholes and pipe casing when hole boring in broken ores: 1-an indenter; 2 -a joint of the indenter and a casing pipe; 3 - a casing pipe; 4 -a drilling rod; 5 -a zone of resistance to drilling; $P$ - the axis load of the rig; $M-t h e$ drilling torque; $P_{1}-$ the reaction of resistance to drilling; $M_{1}-$ the anti-drilling moment; $P_{2}-$ gravitation pressure; $F$ - friction force

In drilling broken ores, dynamic loads on the indenter increase as compared to drilling in monolithic rocks.

The penetration speed under the axial load of 800 and $2000 \mathrm{~kg}$ is described by the graph of the same type (Fig. 6).

To describe the penetration speed under the axial load of 800 and $2000 \mathrm{~kg}$, graphs of exponential and logarithmical dependencies are built

The logarithmical approximation reveals that with the increased rotation speed, the penetration speed also increases (Fig. 7).

The penetration speed of horizontal holes with the increased length decreases under the overload of overlying rocks (Fig. 8).

The dependency of the penetration speed of vertical holes on the rotation speed of the indenter is characterized by Figures $9-11$.

The penetration speed is approximated by the graphs (Figs. 9-11).

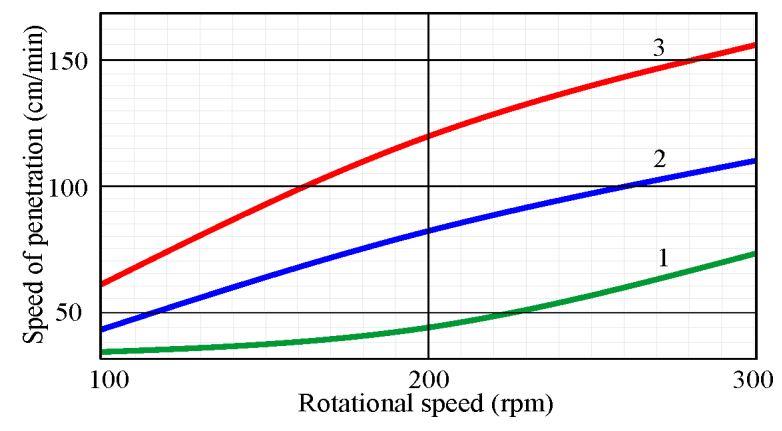

Figure 6. The dependency of the penetration speed of horizontal holes on the rotation speed of the indenter under the axial load of $800 \mathrm{~kg}$ : 1-minimum; 2 -average; 3 -maximum

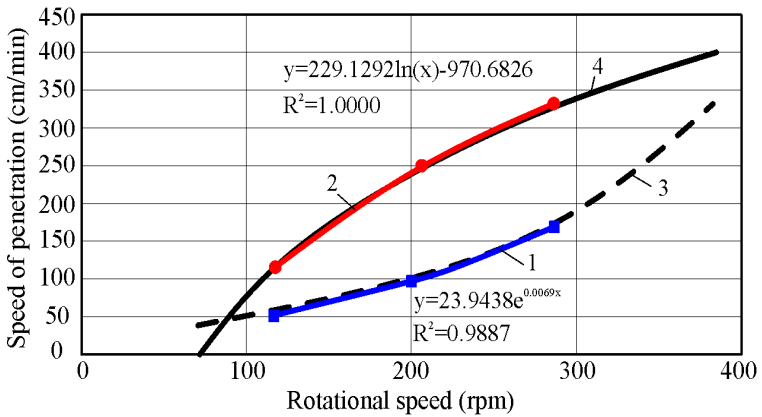

Figure 7. Dynamics of the penetration speed increase of horizontal holes: the average penetration speed: 1 -under the axial load of $800 \mathrm{~kg} ; 2$-under the axial load of $2000 \mathrm{~kg} ; 3$ - the exponential one under the axial load of $800 \mathrm{~kg} ; 4$-the logarithmical one under the axial load of $2000 \mathrm{~kg}$

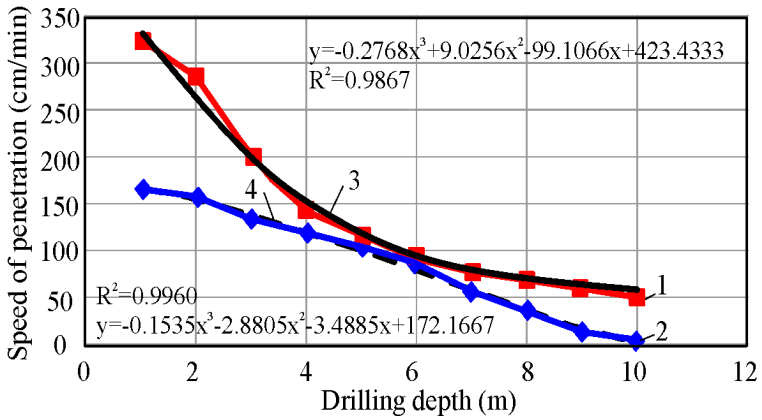

Figure 8. Dependencies of the penetration speed of horizontal holes on their length: 1 -under the axial load of $800 \mathrm{~kg} ; 2$ - under the axial load of $2000 \mathrm{~kg} ; 3$-the polynomial one under the axial load of $800 \mathrm{~kg}$; 4 - the polynomial on under the axial load of $2000 \mathrm{~kg}$

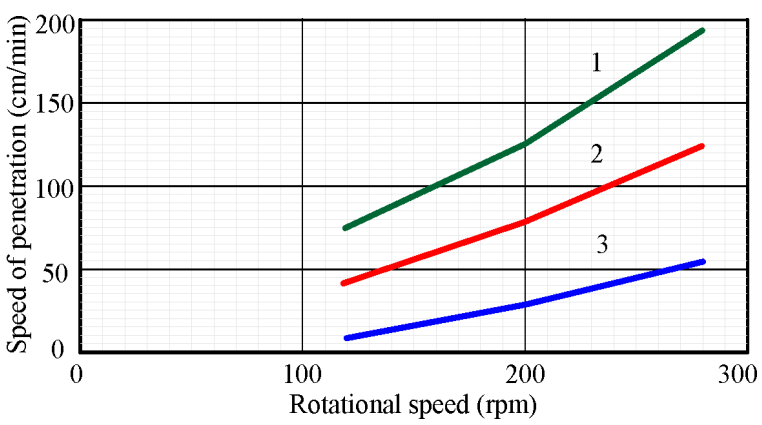

Figure 9. The penetration speed of horizontal holes under the axial load of $800 \mathrm{~kg}$ : 1-maximum; 2-average; 3-minimum 


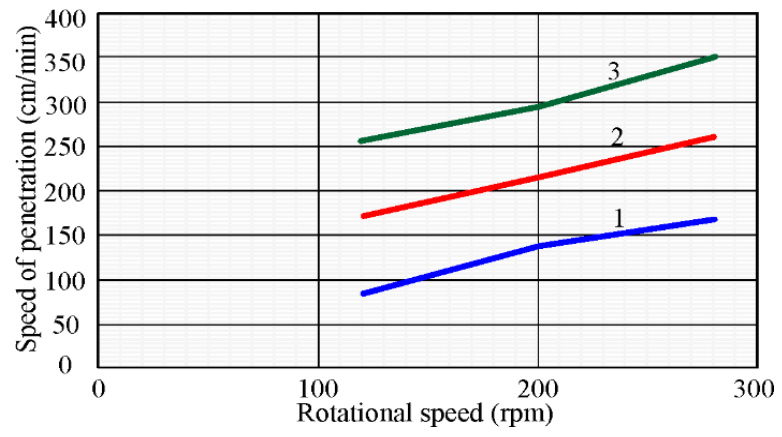

Figure 10. The penetration speed of horizontal holes under the axial load of $2000 \mathrm{~kg}: 1$-maximum; 2 - average; 3 - minimum

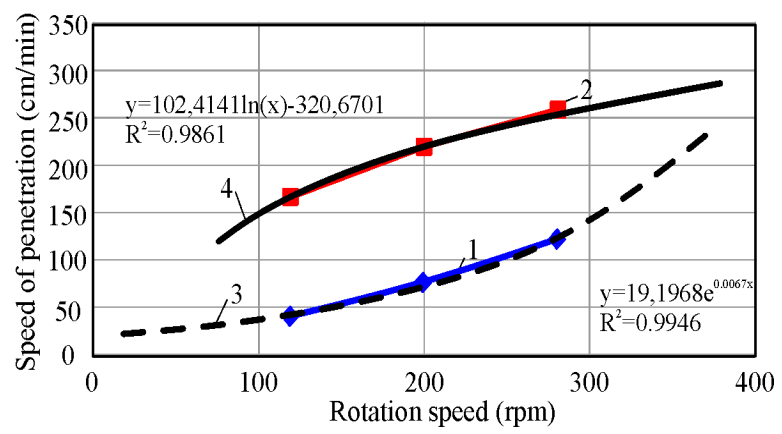

Figure 11. Dynamics of the penetration speed increase of vertical holes: the average penetration speed: 1 -under the axial load of $800 \mathrm{~kg} ; 2$-under the axial load of $2000 \mathrm{~kg} ; 3$ - the exponential one under the axial load of $800 \mathrm{~kg}$; 4 -the logarithmical one under the axial load of $2000 \mathrm{~kg}$

The penetration speed with polyethylene pipe casing changes with depth (Fig. 12).

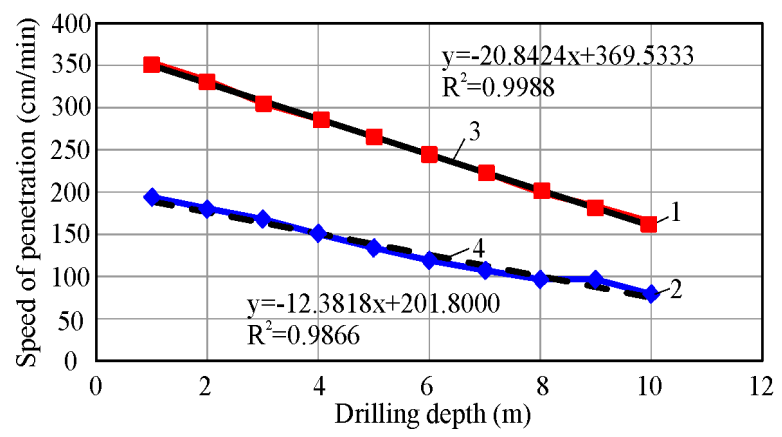

Figure 12. The dependency of penetration speed of vertical holes on their length: 1 -under the axial load of $800 \mathrm{~kg} ; 2$ - under the axial load of $2000 \mathrm{~kg} ; 3$ - the linear one under the axial load of $800 \mathrm{~kg}, 4-$ the linear one under the axial load of $2000 \mathrm{~kg}$

The novelty of the solution implies that the coupling unit of the drilling rod and the pipe delivers the axial load to the pipe to shift it inside the hole without transmitting torque loads on the pipes. Compression loads include the pipe weight and its resistance to shifting inside the hole. When the drift of the descending holes increases, their action decreases to zero in the vertical hole. At the interface of the junction and the rig, friction forces act as a sliding pair, while the junction and the pipe are fixedly connected. The junction contains a device for isolation of rigs, the indenter and casing pipes after drilling.
Drilling occurs within the system:

$P=f(F, \alpha, L, m)$,

where:

$P$ - the breaking point;

$F$ - friction of the pipe surface;

$\alpha$ - the inclination angle of a hole;

$L$ - the hole length;

$m$ - the weight of the length unit of the drilling string.

$F=f(\alpha, L, m, \mu)$,

where:

$\mu$ - the external friction coefficient:

$\mu=f \sum_{1}^{n} x$

where:

$x$-denotes mining-geological, mining-technical and other factors like rock pressure, porosity, humidity, looseness, strength, friction, etc.

The speed of rotary drilling is determined by the axial load $(P)$ and the torque $(M)$ :

$V=f(P, M, \infty)$.

The pressure of overlying rocks is:

$Q=2 \gamma\left(\frac{d h}{2}-\frac{2}{d \operatorname{tg} \beta}\right)$,

where:

$\gamma$ - the volume weight of rocks, $\mathrm{t} / \mathrm{m}^{3}$;

$d$ - the hole length;

$h$ - the height of the roof arch, m;

$\beta$ - the angle of the internal rock friction.

With the borehole inclination the value $Q$ is divided into the normal $F_{n}=Q \cos \alpha$ and the tangential $F_{t}=Q \sin \alpha$.

In drilling a vertical hole, the rock pressure is:

$P_{B}=\gamma H K_{p}$,

where:

$H$ - the operation depth, m;

$K_{p}$ - the thrust ration:

$K_{p}=\operatorname{tg} \frac{90^{\circ}-\beta_{B C}}{2}$,

where:

$\beta_{b c}$ - the angle of the internal rock resistance.

The possibility to bore holes in the broken ore is determined by the model:

$P \geq Q=2 \gamma\left(\frac{d h}{2}-\frac{2}{d \operatorname{tg} \beta}\right) \cdot \cos \int_{0}^{90} \infty$,

where:

$P$ - the axial load of the drilling rig;

$Q$ - rock pressure;

$\alpha$ - the hole spudding angle. 
Regularities of interaction of the indenter and the broken ore are determined by mechanical and energy parameters of drilling which are considered while solving the problem of lost ore recovery by intensifying ore drawing through blasting.

Possible deviations in boring horizontal and inclined holes include $0.05-0.06 \mathrm{grad} / \mathrm{m}$ (angular), $3.5-4.0 \mathrm{~cm} / \mathrm{m}$ (linear).

Durability of junctions and parts, $\mathrm{m}$ : the grief stem 150 , the splined junction of the string -230 , the adapter of the grief stem - 120, the cams of the hydraulic cartridge -58 .

Specific capacity consumption in boring horizontal holes by $76 \mathrm{~mm}$ roller bits makes $0.8-1.0 \mathrm{~kW} \cdot \mathrm{t} / \mathrm{m}$.

Figure 13 shows an efficient design of the string. Blasting in the compressed medium allows reducing the specific explosive charge and applying cheaper explosives with less explosion heat. In the area of the controlled explosive action (15 radii of the charge), there is a net of macro-fractures exceeding the lump surface by 3 orders of magnitude (Wang et al., 2012; Yun, Rylnikova, \& Terentyeva, 2015; Dmitrak \& Kamnev, 2016).

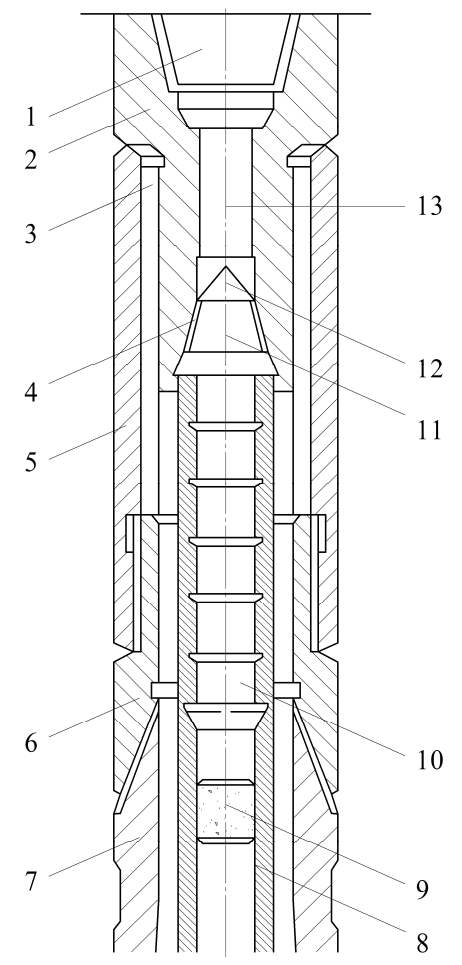

Figure 13. The design of a drilling string: $1-$ a roller bit; 2 - a splined shaft-adapter; 3 -splines; 4 - a conical threaded centralizer of the shaft-adapter; 5 -a splined cup; 6 - an adapter; 7 -a drilling rod; 8 -a polyethylene hose; 9-a wooden plug; 10 - a tip; $11-a$ conical threaded centralizer of the tip; 12 - a guide taper of the tip; 13 -a place for attaching an aluminum rivet

Application of small delay intervals between hole charges allows affecting the massif before its shift and increasing absorption of explosive energy. After each explosive pulse, the explosion wave speed and the elasticity modulus decrease while, the Poisson's ratio increases (Wang, Huang, Wu, \& Ma, 2011; O’Sullivan \& Newman, 2014; Komashchenko, Vasilyev, \& Maslennikov, 2016).
The ore drawing enhanced through blasting is associated with rock movements and displacement. Changes in the in-situ stress state are observed by means of soundintercepting devices. Examination of blasthole walls provides data on stratification of the roof (Capilla \& Delgado, 2015; Lyashenko, Nebogin, \& Alekhin, 2015; Komashchenko, 2016).

Obtained regularities of creating secondary ore massifs, behaviour of packed rocks, parameters of the drilling string operation, the model of interaction of the indenter and the broken rocks, the concept of controlling the efficiency of the secondary mining and the mathematical model of the environmental and economic assessment of the technology can be used when improving lost ore drawing in mineral mining (Bahri Najafi, Saeedi \& Ebrahimi Farsangi, 2014; Golik, Komaschenko, Morkun, \& Khasheva, 2015; Kaplunov, Rylnikova, \& Radchenko, 2015).

Radical reduction of ore losses and dilution caused by overlying and side rocks in case of improved control over ore distribution compensates increased mining expenses due to the applied blasthole drilling technology.

If operating costs increase, the new technology of blasthole drilling in broken ores will provide profits depending on the amount of its application.

\section{CONCLUSIONS}

The mineral recovery ratio in underground mining increases with enhanced ore drawing through blasting in broken ores. The efficient drawing of packed ores is determined by properties of a structure of blocked ore joints and technical means of breaking ores. Hole drilling indices in broken ores are conditioned by the character and parameters of interaction of the string indenter and broken ores and rocks.

\section{ACKNOWLEDGEMENTS}

No founding to declare. Authors express gratitude for the help and consultations during work performing for Rector of Kryvyi Rih National University Professor Mykola Stupnik.

\section{REFERENCES}

Bahri Najafi, A., Saeedi, G.R., \& Ebrahimi Farsangi, M.A. (2014). Risk analysis and prediction of out-of-seam dilution in longwall mining. International Journal of Rock Mechanics and Mining Sciences, (70), 115-122. https://doi.org/10.1016/j.ijrmms.2014.04.015

Benardos, A., Athanasiadis, I., \& Katsoulakos, N. (2014). Modern earth sheltered constructions: a paradigm of green engineering. Tunnelling and Underground Space Techno$\log y,(41), 46-52$. https://doi.org/10.1016/j.tust.2013.11.008

Bowman, S. (2016). Interferometric synthetic aperture radar (InSAR). Back-ground and application: guidelines for investigating geologic hazards and preparing engineering geology reports, with a suggested approach to geologichazard ordinances in Utah. The University of Utah, 198-203.

Bubnov, V., Spirin, E., Kapkanshchikov, A., Golik, V., Smirnov, Y., Vorobyev, A., Sytnikov, A., Yevseyev, L., Pigulskiy, V., Zabortsev, S., Rudenko, N., Bereza, V., \& Shamonin, V. (1992). Teoriya i praktika dobychi poleznykh 
iskopayemykh dlya kombinirovannykh sposobov vyshchelachivaniya. Akmola, Kazakhstan: Zha-on-Arch.

Capilla, A., \& Delgado, A. (2015). The destiny of the Earth's mineral resources. London, United Kingtom: World Scientific Publishing Co. Pte. Ltd.

Demchenko, O., Evtekhov, V., \& Georgiieva, H. (2017). Mineral composition of high-grade iron ores that are one of the components of coarse grained screenings from crushing and screening plants in the Kryvyi Rih basin. Visnyk of Taras Shevchenko National University of Kyiv. Geology, 2(77), 77-81. https://doi.org/10.17721/1728-2713.77.09

Dmitrak, Y., \& Kamnev, Y. (2016). Vedushchiy proyektnoizyskatelskiy i nauchno-issledovatelskiy institut promyshlennoy tekhnologii - put dlinoy v 65 let. Gornyy Zhurnal, (3), 6-12.

Golik, V., Komaschenko, V., Morkun, V., \& Burdzieva, O. (2015). Modelling of rock massifs tension at underground ore mining. Metallurgical and Mining Industry, (8), 540-543.

Golik, V., Komaschenko, V., Morkun, V., \& Khasheva, Z. (2015). The effectiveness of combining the stages of ore fields development, Metallurgical and Mining Industry, 7(5), 401-405.

Golik, V., Komashchenko, V., Morkun, V., \& Burdzieva, O. (2017). Experience of metal deposits combined development for South African enterprises. Mining of Mineral Deposits, 11(2), 68-78. https://doi.org/10.15407/mining11.02.068

Gur'yeva, Y. (2009). Povysheniye polnoty ispolzovaniya nedr intensifikatsiyey vypuska pri dobyche poteryannykh rud. $\mathrm{PhD}$ Thesis. Vladikavkaz, Russian Federation: SeveroKavkazskiy gorno-metallurgicheskiy institut.

Iofis, M., Fedorov, E., Yesina, E., \& Miletenko, N. (2017). Razvitiye geomekhaniki dlya resheniya problem sokhraneniya zemnykh nedr. Gornyy Zhurnal, (11), 67-74.

Kaplunov, D., Rylnikova, M., \& Radchenko, D. (2015). Nauchno-metodicheskiye osnovy proyektirovaniya ekologicheski sbalansirovannogo tsikla kompleksnogo osvoyeniya i sokhraneniya nedr Zemli. Gornyy Informatsionno-Analiticheskiy Byulleten, 4(15), 5-11.

Komashchenko, V. (2016). Razrabotka vzryvnoy tekhnologii, snizhayushchey vrednoye vozdeystviye na okruzhayushchuyu sredu. Izvestiya Tul'skogo gosudarstvennogo universiteta. Nauki o Zemle, (1), 34-43.

Komashchenko, V., Vasilyev, P., \& Maslennikov, S. (2016). Tekhnologiyam podzemnoy razrabotki mestorozhdeniy KMA - nadezhnuyu syr'yevuyu osnovu. Izvestiya Tul'skogo gosudarstvennogo universiteta. Nauki o Zemle, (2), 101-114.

Luk'yanov, V.G., Komashchenko, V.I., \& Shmurygin, V.A. (2017). Vzryvnyye raboty. Tomsk, Russian Federation: Natsionalnyy issledovatel'skiy Tomskiy politekhnicheskiy universitet.

Lyashenko, V., Nebogin, V., \& Alekhin, A. (2015). Povysheniye ekologicheskoy bezopasnosti proizvodstva vzryvnykh rabot $\mathrm{s}$ pomoshch'yu emul'sionnykh vzryvchatykh veshchestv na kar'yerakh Ukrainy. ZAO NTTS PB. Bezopasnost' truda $v$ promyshlennosti, (4), 38-45.

Olovyannyy, A. (2016). Bokovoy raspor i tektonicheskiye napryazheniya v massive gornykh porod. Gornyy Zhurnal, (4), 25-31.

O'Sullivan, D., \& Newman, A. (2014). Extraction and backfill scheduling in a complex underground mine. Interfaces, 44(2), 204-221. https://doi.org/10.1287/inte.2013.0730

Wang, W., Huang, S., Wu, X., \& Ma, Q. (2011). Calculation and management for mining loss and dilution under 3D visualization technical condition. Journal of Software Engineering and Applications, 04(05), 329-334. https://doi.org/10.4236/jsea.2011.45037

Wang, H., He, Y., Duan, C., Zhao, Y., Tao, Y., \& Ye, C. (2012). Development of mineral processing engineering education in China University of Mining and Technology. Advances in Computer Science and Engineering, 77-83. https://doi.org/10.1007/978-3-642-27948-5 11

Yun, A., Rylnikova, M., \& Terentyeva, I. (2015). O perspektivakh i strategii osvoyeniya Zhezkazganskogo mestorozhdeniya. Gornyy Zhurnal, (5), 44-49.

\section{ВДОСКОНАЛЕННЯ ТЕХНОЛОГІЇ БУРІННЯ СВЕРДЛОВИН ДЛЯ ІНТЕНСИФІКАЦІї ВИПУСКУ РУД}

\section{В. Голик, В. Моркун, Н. Моркун, І. Гапоненко}

Мета. Вдосконалення технології буріння свердловин для підвищення повноти використання надр шляхом інтенсифікації випуску руд підриванням зарядів вибухових речовин (ВР).

Методика. Параметри буріння досліджені на породному відвалі. Засоби експериментального буріння: буровий верстат СКБ-4; бурові штанги діаметром 42 мм довжиною 1.2 м; поліетиленові труби ПНД $63 \times 8$ та ПНД 70×8 довжиною 1.2 м; сталеві муфти для з'єднання поліетиленових труб; шарошечні долота та різці РКС. Критерієм ефективності буріння була механічна швидкість буріння. Швидкість буріння на різних глибинах вимірювали при осьовому зусиллі 800 - 2000 кг і швидкостях обертання 120, 200 і 280 об/хв. Експериментальне буріння здійснювалося із застосуванням снарядів двох модифікацій. Пробурено 18 експериментальних свердловин довжиною $300 \mathrm{M}$.

Результати. Підтверджена можливість та доцільність буріння свердловин одночасно з установкою обсадних труб без передачі на останні навантажень від крутного моменту. Запропоновано конструкції бурового снаряду для установки обсадних труб із розміщенням шлангів всередині бурових штанг і подальшим їх вилученням та 3 установкою обсадних труб одночасно з бурінням. Складено схему взаємодії сил при бурінні у зруйнованому масиві свердловин з обсадкою. Досліджено характер взаємозв'язку швидкості проходки вертикальних і горизонтальних свердловин зі зміною осьового зусилля та їх довжини при різних модифікаціях бурового снаряду.

Наукова новизна. Отримано нові закономірності зміни швидкості проходки свердловин залежно від комплексу технологічних параметрів буріння. Запропоновано модель опису можливості буріння свердловин по зруйнованому масиву й оптимізована конструкція снаряду для іiі реалізації.

Практична значимість. Отримані закономірності визначають механічні та енергетичні показники буріння, які необхідні на стадії проектування при вирішенні питання щодо доцільності вилучення втрачених руд при вдосконаленні технології розробки родовищ із випуском втрачених руд.

Ключові слова: інтенсифікація випуску, злежалі руди, свердловина, буровий снаряд, обсадна труба 


\section{СОВЕРШЕНСТВОВАНИЕ ТЕХНОЛОГИИ БУРЕНИЯ СКВАЖИН ДЛЯ ИНТЕНСИФИКАЦИИ ВЫПУСКА РУД}

\section{В. Голик, В. Моркун, Н. Моркун, И. Гапоненко}

Цель. Совершенствование технологии бурения скважин для повышения полноты использования недр путем интенсификации выпуска руд взрыванием зарядов взрывчатых веществ (BВ).

Методика. Параметры бурения исследованы на породном отвале. Средства экспериментального бурения: буровой станок СКБ-4; буровые штанги диаметром 42 мм длиной 1.2 м; полиэтиленовые трубы ПНД $63 \times 8$ и ПНД 70×8 длиной $1.2 \mathrm{м}$; стальные муфты для соединения полиэтиленовых труб; шарошечные долота и резцы РКС. Критерием эффективности бурения являлась механическая скорость бурения. Скорость бурения на разных глубинах измеряли при осевом усилии $800-2000$ кг и скоростях вращения 120, 200 и 280 об/мин. Экспериментальное бурение осуществлялось с применением снарядов двух модификаций. Пробурено 18 экспериментальных скважин длиной 300 м.

Результаты. Подтверждена возможность и целесообразность бурения скважин одновременно с установкой обсадных труб без передачи на последние нагрузок от крутящего момента. Предложены конструкции бурового снаряда для установки обсадных труб с размещением шлангов внутри буровых штанг и последующим их извлечением и с установкой обсадных труб одновременно с бурением. Составлена схема взаимодействия сил при бурении в разрушенном массиве скважин с обсадкой. Исследован характер взаимосвязи скорости проходки вертикальных и горизонтальных скважин с изменением осевого усилия и их длины при разных модификациях бурового снаряда.

Научная новизна. Получены новые закономерности изменения скорости проходки скважин в зависимости от комплекса технологических параметров бурения. Предложена модель описания возможности бурения скважин по разрушенному массиву и оптимизированная конструкция снаряда для ее реализации.

Практическая значимость. Полученные закономерности определяют механические и энергетические показатели бурения, которые необходимы на стадии проектирования при решении вопроса о целесообразности извлечения потерянных руд при совершенствовании технологии разработки месторождений с выпуском потерянных руд.

Ключевые слова: интенсификация выпуска, слежавшиеся руды, скважина, буровой снаряд, обсадная труба

\section{ARTICLE INFO}

Received: 28 February 2018

Accepted: 8 August 2018

Available online: 22 August 2018

\section{ABOUT AUTHORS}

Vladimir Golik, Doctor of Technical Sciences, Professor of the Mining Department, North Caucasian Mining and Metallurgical Institute (State Technological University), 44 Nikolaeva St, 362021, Vladikavkaz, Russian Federation. E-mail: v.i.golik@mail.ru

Volodymyr Morkun, Doctor of Technical Sciences, Vice Rector for Research of the Kryvyi Rih National University, 11 Matusevycha St, 50027, Kryvyi Rih, Ukraine. E-mail: morkunv@gmail.com

Nataliia Morkun, Doctor of Technical Sciences, Head of the Automation, Computer Sciences and Technologies Department, Kryvyi Rih National University, 11 Matusevycha St, 50027, Kryvyi Rih, Ukraine. E-mail: nmorkun@gmail.com

Iryna Gaponenko, Senior Researcher of the Science and Research Section, Kryvyi Rih National University, 11 Matusevycha St, 50027, Kryvyi Rih, Ukraine. E-mail: irinagaponenko44@gmail.com 